REVIEW ARTICLE

\title{
I 期非小細胞肺癌に対する定位放射線治療の臨床研究のレビュー
}

\author{
大西 洋 1 ・荒木 力1
}

\section{Review of Clinical Studies of Stereotactic Body Radiotherapy for Stage I Non-small Cell Lung Cancer}

\author{
Hiroshi Onishi1; Tsutomu Araki1 \\ ${ }^{1}$ Department of Radiology, University of Yamanashi, Japan.
}

\begin{abstract}
Stereotactic body radiotherapy (SBRT) has been regularly applied mainly for inoperable patients with stage I non-small cell lung cancer from approximately 1995, and various clinical trials have been performed in Japan. Uematsu et al. (2001) reported that the 3-year local control and overall survival rates of SBRT (50-60 Gy in 10 fractions) were $94 \%$ and $66 \%$, respectively. Nagata et al. (2005) reported that the 3-year overall survival rate of SBRT ( $48 \mathrm{~Gy}$ in 4 fractions) was $83 \%$ in stage IA and $72 \%$ in stage IB. Onishi et al. reported that both local control and survival rates were better with a biologically effective dose of $100 \mathrm{~Gy}$ or more than those given less than $100 \mathrm{~Gy}$ in a multi-institutional retrospective study in Japan. In the USA, Timmerman et al. reported that the maximum tolerable dose was $60 \mathrm{~Gy}$ in 3 fractions in a phase I study, and the 3-year local control and overall survival rates were $98 \%$ and $56 \%$, respectively, in a phase II trial using the same protocol (RTOG0236). In Japan, a phase II trial of SBRT with $48 \mathrm{~Gy}$ in 4 fractions for stage IA (JCOG0403) has been completed, with a total enrollment of 165 patients, and the results of the operable patients subgroup was presented in 2010. Enrollment for a phase II trial for operable patients (RTOG0618) has also been completed.
\end{abstract}

KEY WORDS — Stereotactic body radiotherapy, Non-small cell lung cancer, Stage I, Clinical trial

(JJLC. 2012;52:168-173)

Reprints: Hiroshi Onishi, Department of Radiology, University of Yamanashi, 1110 Shimokato, Chuo-city, Yamanashi 409-3898, Japan (e-mail: honishi@yamanashi.ac.jp).

要旨——I期非小細胞肺癌に対する定位放射線治療は 1995 年頃から主に手術困難な患者に対して臨床応用が 活発となり，さまざまな臨床試験が行われている．初期 の報告としては, Uematsu らが 2001 年に, 50〜60 Gy/10 回法で 3 年局所制御率が $94 \%, 3$ 年粗生存率が $66 \%$ と報 告した. 次いで Nagata らが 2005 年に, $48 \mathrm{~Gy} / 4$ 回法で 3 年局所制御率が $98 \%, 3$ 年粗生存率が IA 期で $83 \%$. IB 期で $72 \%$ と報告した. Onishi らは多施設研究で biological effective dose (BED) が $100 \mathrm{~Gy}$ 以上の群で局所制 御率・生存率ともに良好であると報告した。米国では
Timmerman らが第 I 相（線量増加）試験結果として 60 $\mathrm{Gy} / 3$ 回が最大許容線量とした. 次にRTOG0236 として $60 \mathrm{~Gy} / 3$ 回法の第 II 相試験が行われ, 3 年局所制御率 $98 \%, 3$ 年粗生存率 $56 \%$ と報告された. 日本では IA 期に 対する $48 \mathrm{~Gy} / 4$ 回法の第 II 相試験がJCOG0403 として 全 165 症例が登録完了し, そのうち手術可能症例群の 3 年成績が 2010 年学会発表された. 米国でも手術可能症例 に対する第 II 相試験(RTOG0618)が登録終了している. 索引用語——定位放射線治療, 非小細胞肺癌, I 期, 臨 床研究
1山梨大学医学部放射線科.

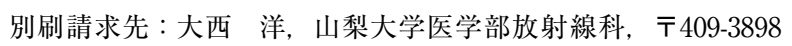
山梨県中央市下河東 1110 (e-mail: honishi@yamanashi.ac.jp).
※第 51 回日本肺癌学会総会シンポジウム「肺癌に対する高精度 放射線治療の現状」. 


\section{1. はじめに}

肺癌は世界で最も主要な癌腫であり，日本ではがん死 因別で男女ともに 1 位である. 近年は, CT 診断の普及に よって早期肺癌が多く見つかるようになった．現時点で 早期肺癌の標準的治療は外科手術であるが, 高齢化が急 速に進行し, 手術困難な症例が増加している状況の中, 低侵襲治療である定位放射線治療の効果と安全性を明ら かにすることは非常に意義が大きいと考える. 本稿では, I 期非小細胞肺癌に対する定位放射線治療についてのこ れまでの臨床試験の内容や今後の課題について概説す る.

\section{2. 定位放射線治療の定義と歴史}

1990 年代半ばから急速に発展した照射関連機器の進 歩の中で 3 次元的照射が可能となり, 固定精度の向上や image-guide などの関連技術の発展とともに 1995 年頃 から定位照射手法が少しずつ肺癌に対して臨床応用され 始めた. 1,2

定位放射線治療の定義を満たすための照射条件は以下 の通りである. 3 (1)治療計画時と実照射時の間における $5 \mathrm{~mm}$ 以内の照射中心位置の再現抢よび固定精度, (2)呼 吸移動性を縮小する対策, (3) 3 次元的多方向からの多 ビーム収束による腫瘍への線量集中, (4) 1 回大線量（一 般的には $5 \mathrm{~Gy}$ 以上) での短期間治療（一般的には 2 週間 以内),の 4 つである.肺癌に関しての保険適応上は, 直 径が $5 \mathrm{~cm}$ 以内で転移病巣のない原発性肺癌，または原 発病巣が制御されており，他病巣のない直径が $5 \mathrm{~cm}$ 以 内の 3 個までの転移性肺癌となっている. 2004 年度から 保険収載され，治療計画から全治療を含んで全体で 63000 点が診療報酬とされている.

Nagata らの全国調查によると, 2005 年までの時点で 日本では 53 施設で体幹部定位放射線治療が行われてお り, 肺癌に対しては 2104 人（原発性肺癌 1111 人，転移 性肺癌 702 人, 組織未確定 291 人）が定位照射で治療さ れたと報告されている 4 が，抢そらくその後照射患者数 は飛躍的に増加していると思われる。

\section{3. 第 I 相臨床試験（線量増加試験）}

日本では肺癌に対する厳密な第 I 相臨床試験は存在せ ず, 後述する遡及的研究結果から, biological effective dose (BED) で $100 \mathrm{~Gy}$ を超える線量で満足のいく局所制 御が得られていると判断されて, ${ }^{5}$ 臨床試験や実地医療 での処方線量がほぼ固定された．先述の Nagataらの調 查で最も頻度の高かった線量分割は $12 \mathrm{~Gy} \times 4$ 回法, で あった. ${ }^{4}$

一方米国では $8 \mathrm{~Gy} \times 3$ 回からの線量増加試験が行わ
れ, $20 \mathrm{~Gy} \times 3$ 回が最大許容線量として設定された. $6.7 こ$ の時に報告された線量制限毒性は grade 3〜4の皮虐炎, 心膜炎, 肺炎, 気管壞死などであった。この結果を受け て, その後欧米では主に $20 \mathrm{~Gy} \times 3$ 回で実地診療が行われ るようになった. 日本では $12 \mathrm{~Gy} \times 4$ 回法が標準的に行わ れているが, 腫瘍サイズが大きくなると局所制御が低下 するという報告が多く, 8.9 T2N0M0 非小細胞肺癌に対 して日本で線量増加試験 (JCOG0702) が行われている.

\section{4. 主に手術不能患者に対する後ろ向き研究}

I 期非小細胞肺癌の標準治療は言うまでもなく手術で あるため, 定位放射線治療は初期には専ら手術適応のな い患者に対して行われた。一部には，患者の手術拒否に よる手術不能患者が少数含まれていた. 手術不能患者を 中心にした対象群に対する主な遡及的研究結果を Table 1 に示す. 5,8,10-12 発表者によって照射方法や処方線量が まちまちなために結果は異なるが, 十分な線量が処方さ れた場合の局所制御効果は $90 \%$ を超えることが示唆さ れている．ただし，後述するように生存期間は十分に長 くないため, 長期経過観察した場合の局所制御率につい ては十分なデータではない。 また, 生存率についてはば らつきが大きく手術結果と比べて良好とは言えないが, 手術不能な高齢者や状態不良な対象が多く, 他因死が多 いからではないかと考えられる.

\section{5. 手術可能（拒否）患者に対する後ろ向き研究}

手術適応があるにも関わらず患者の希望で定位放射線 治療を選択した患者数は単一施設では多くないため, 日 本の多施設集積データから手術可能症例を抽出して分析 した報告がある. 9,13 BED で $100 \mathrm{~Gy}$ を超える線量投与 で, $100 \mathrm{~Gy}$ 未満症例群よりも良好な局所制御率と生存率 が得られており, BED で $100 \mathrm{~Gy}$ を超える症例群 87 症例 (中間年齢 74 歳) での 5 年局所無増悪率と 5 年生存率は IA 期と IB 期でそれぞれ $90 \% ， 74 \% ， 89 \% ， 58 \%$ であっ た (中間観察期間が 58 ケ月). 死因の中で他病死が $38 \%$ と多くを占めていた. grade 3 以上の有害事象は $2 \%$ で あったが, 後ろ向き研究のため有害事象については十分 に評価されていない可能性がある.

\section{6. 標準手術不能患者に対する第 II 相臨床試験研究}

Table 1 に示すような初期の良好な局所制御効果に基 づき, 標準手術不可能患者に対する第 II 相臨床試験が相 次いで行われた. 主な結果を Table 2 に示す. 14-20 日欧米 で設定された処方線量は異なるが, $90 \%$ 以上の 3 年局所 制御率や生存率のばらつきについて, 後ろ向き研究結果 とほほ同様である。ただ，有害事象については grade 3 以上の発生率が後乃向き研究結果よりも大きい報告があ 
Table 1. Results of Retrospective Studies of Stereotactic Body Radiotherapy Mainly for Inoperable Patients with Stage I Non-small Cell Lung Cancer

\begin{tabular}{|c|c|c|c|c|c|c|c|}
\hline Author & $\begin{array}{l}\text { No. of } \\
\text { patients }\end{array}$ & $\begin{array}{c}\text { Age } \\
\text { range } \\
\text { (years) } \\
\text { (median) }\end{array}$ & $\begin{array}{c}\text { Dose } \\
\text { Gy/fraction (fx) }\end{array}$ & $\begin{array}{l}\text { Median } \\
\text { follow-up } \\
\text { period } \\
\text { (months) }\end{array}$ & $\begin{array}{c}\text { 3-year overall } \\
\text { survival rate } \\
\quad+\text { stage }\end{array}$ & $\begin{array}{l}\text { Local } \\
\text { control }\end{array}$ & Complications \\
\hline $\begin{array}{l}\text { Uematsu }^{10} \\
(2001)\end{array}$ & 50 & $\begin{array}{c}54-86 \\
(71)\end{array}$ & $50-60 \mathrm{~Gy} / 5-10 \mathrm{fx}$ & 36 & $66 \%$ & $94 \%$ & Rib fracture: $2 \%$ \\
\hline $\begin{array}{l}\operatorname{Hof}^{11} \\
(2003)\end{array}$ & 10 & $\begin{array}{c}58-83 \\
(71)\end{array}$ & $19-26 \mathrm{~Gy} / 1 \mathrm{fx}$ & 15 & $37 \%$ & $60 \%$ & $\begin{array}{l}\text { No complications }>\text { RTOG grade } \\
2\end{array}$ \\
\hline $\begin{array}{l}\text { Onishi }^{5} \\
\text { (2004) }\end{array}$ & 35 & $\begin{array}{c}65-92 \\
(71)\end{array}$ & $60 \mathrm{~Gy} / 10 \mathrm{fx}$ & 13 & $\begin{array}{l}64 \% \\
\text { (at } 2 \text { years) }\end{array}$ & $88 \%$ & $\begin{array}{l}\text { NCI-CTC (V2) grade } 3 \text { pneumo- } \\
\text { nia: } 9 \%\end{array}$ \\
\hline $\begin{array}{l}\text { Onimaru }{ }^{8} \\
(2008)\end{array}$ & 28 & $\begin{array}{c}52-85 \\
(76)\end{array}$ & $48 \mathrm{~Gy} / 4 \mathrm{fx}$ & 27 & $\begin{array}{l}\text { IA } 82 \% \\
\text { IB } 32 \%\end{array}$ & $64 \%$ & $\begin{array}{l}\text { NCI-CTC (V3.0) grade } 3 \text { pneumo- } \\
\text { nia: } 4 \%\end{array}$ \\
\hline $\begin{array}{l}\text { Takeda }^{12} \\
\text { (2009) }\end{array}$ & 63 & $\begin{array}{c}56-91 \\
(78)\end{array}$ & $50 \mathrm{~Gy} / 5 \mathrm{fx}$ & 31 & $\begin{array}{l}\text { IA } 90 \% \\
\text { IB } 63 \%\end{array}$ & $95 \%$ & $\begin{array}{l}\text { NCI-CTC (V3.0) grade } 3 \text { pneumo } \\
\text { nia: } 3 \%\end{array}$ \\
\hline
\end{tabular}

Table 2. Results of Phase II Trials of Stereotactic Body Radiotherapy Mainly for Inoperable Patients with Stage I Nonsmall Cell Lung Cancer

\begin{tabular}{|c|c|c|c|c|c|c|c|}
\hline Author & $\begin{array}{l}\text { No. of } \\
\text { patients }\end{array}$ & $\begin{array}{l}\text { Age } \\
\text { range } \\
\text { (years) } \\
\text { (median) }\end{array}$ & $\begin{array}{l}\text { Dose } \\
\text { Gy/fraction } \\
\text { (fx) } \\
\text { (prescription) }\end{array}$ & $\begin{array}{l}\text { Median } \\
\text { follow-up } \\
\text { period } \\
\text { (months) }\end{array}$ & $\begin{array}{l}\text { 3-year overall } \\
\text { survival rate } \\
\quad+\text { stage }\end{array}$ & $\begin{array}{l}\text { 3-year local } \\
\text { control }\end{array}$ & Complications \\
\hline $\begin{array}{l}\text { Nagata }^{14} \\
\text { (2005) }\end{array}$ & 42 & $\begin{array}{c}51-87 \\
(77)\end{array}$ & $\begin{array}{l}48 \mathrm{~Gy} / 4 \mathrm{fx} \\
\text { (tumor center) }\end{array}$ & 30 & $\begin{array}{l}\text { IA } 83 \% \\
\text { IB } 72 \%\end{array}$ & $98 \%$ & NCI-CTC (V2) grade 2 pneumonia: $4 \%$ \\
\hline $\begin{array}{l}\text { Zimmermann }{ }^{15} \\
(2006)\end{array}$ & 68 & $\begin{array}{c}59-92 \\
(76)\end{array}$ & $\begin{array}{l}37.5 \mathrm{~Gy} / 3-5 \mathrm{fx} \\
\text { (60\% isodose) }\end{array}$ & 17 & $53 \%$ & $94 \%$ & $\begin{array}{l}\text { RTOG grade } 3 \text { pneumonia: } 6 \% \\
\text { Rib fracture: } 3 \%\end{array}$ \\
\hline $\begin{array}{l}\text { Timmerman } \\
\text { (2006) }\end{array}$ & 70 & $\begin{array}{c}51-86 \\
(70)\end{array}$ & $60-66 \mathrm{~Gy} / 3 \mathrm{fx}$ & 18 & $\begin{array}{l}55 \% \\
\text { (at } 2 \text { years) }\end{array}$ & $\begin{array}{l}95 \% \\
\text { (at } 2 \text { years) }\end{array}$ & $\begin{array}{c}\text { NCI-CTC (V2) grades 3-5: 20\% } \\
\text { grade 5: } 8.5 \%\end{array}$ \\
\hline $\begin{array}{l}\text { Baumann } \\
(2006)\end{array}$ & 57 & $\begin{array}{c}59-87 \\
(75)\end{array}$ & $\begin{array}{l}45 \mathrm{~Gy} / 3 \mathrm{fx} \\
(67 \% \text { isodose })\end{array}$ & 35 & $60 \%$ & $92 \%$ & NCI-CTC (V2) grade 3: 28\% \\
\hline $\begin{array}{l}\text { Fakiris }^{17} \\
(2009)\end{array}$ & 70 & Not shown & $\begin{array}{l}\mathrm{T} 1: 60 \mathrm{~Gy} / 3 \mathrm{fx} \\
\mathrm{T} 2: 66 \mathrm{~Gy} / 3 \mathrm{fx} \\
\text { (80\% isodose) }\end{array}$ & 50 & $43 \%$ & $94 \%$ & $\begin{array}{l}\text { Peripheral; NCI-CTC (V2) grades 3-5: } \\
10 \% \\
\text { Central; NCI-CTC (V2) grades 3-5: } \\
27 \%\end{array}$ \\
\hline $\begin{array}{l}\text { Ricardi }^{19} \\
(2010)\end{array}$ & 62 & $\begin{array}{c}53-83 \\
(74)\end{array}$ & $\begin{array}{l}45 \mathrm{~Gy} / 3 \mathrm{fx} \\
\text { ( } 80 \% \text { isodose) }\end{array}$ & 28 & $57 \%$ & $92 \%$ & $\begin{array}{l}\text { Pneumonia } \geq \text { RTOG grade } 3: 3 \% \\
\text { Rib fracture: } 2 \%\end{array}$ \\
\hline $\begin{array}{l}\text { Timmerman } \\
\text { (2010) }\end{array}$ & 55 & $\begin{array}{c}48-89 \\
(72)\end{array}$ & $\begin{array}{l}60 \mathrm{~Gy} / 3 \mathrm{fx} \\
\text { (D95) }\end{array}$ & 34 & $56 \%$ & $98 \%$ & $\begin{array}{l}\text { Grade } 3 \text { NCI-CTC (V3.0): 12.7\% } \\
\text { Grade } 4 \text { NCI-CTC (V3.0): 3.6\% }\end{array}$ \\
\hline
\end{tabular}

るが，前向き研究による定期的で欠落のない経過観察に よるためかもしれない. 特に，気管・葉気管支周辺のい わゆる「中心型」肺癌を含む症例を対象にした 60 ～66 $\mathrm{Gy} / 3$ 回法による定位放射線治療では, grade 3 以上の有 害事象が 70 人中 14 人 $(20 \%)$ に発生し, grade 5 が 6 人 (肺炎 4 人, 心膜炎 1 人, 喀血 1 人)でそのうち 4 例は 中心型であったと報告され, 16 中心型肺癌への投与線量 について Table 3 に示すように米国では $10 \mathrm{~Gy} \times 5$ 回 (RTOG0813), 日本では $7.5 \mathrm{~Gy} \times 8$ 回 (JROSG10-1) から の線量増加試験が施行されることになった.

\section{7. 手術可能患者に対する第 II 相臨床試験}

Japanese Clinical Oncology Group (JCOG) に本研究を
きっかけにして放射線治療グループ(代表：平岡眞寛)が 初めて形成され, 臨床病期 IA 期の非小細胞肺癌に対す る定位放射線治療の第 II 相試験 (JCOG0403) が施行され た. 全例病理学的に確定され, 標準手術可能群と不可能 群の療法が登録されたが, 可能群が先に目標症例数に達 し, 3 年の経過観察の後に 2010 年の米国放射線腫瘍学会 や日本肺癌学会などで, 初期結果が Nagata らによって 報告された. 手術可能症例群に対する第 II 相臨床試験と しては世界で最初の報告であった。学会で報告された内 容から要点を抜粋する. 処方線量はアイソセンタで 48 $\mathrm{Gy} / 4$ 回が処方された. 2004 年 7 月から 2007 年 1 月まで に 65 症例が登録された。平均年齢 79 歳 $(50 \sim 91)$, 男性 45 , 女性 20 , 平均腫瘍径 $21 \mathrm{~mm}(10 \sim 30)$, 組織型では 
Table 3. Ongoing Prospective Studies of SBRT Other Than RTOG0236 and JCOG0702

\begin{tabular}{|c|c|c|}
\hline Trial name & Purpose & Status \\
\hline RTOG0618 & Phase II study for operable T1-3N0M0 NSCLC (60 Gy/3 fx) & Active, not recruiting \\
\hline JCOG0702 & Dose escalation study for T2N0M0 NSCLC (started from 40 Gy/4 fx) & Recruiting \\
\hline RTOG0813 & $\begin{array}{l}\text { Dose escalation study for centrally located stage I NSCLC (started from } \\
50 \mathrm{~Gy} / 5 \mathrm{fx} \text { ) }\end{array}$ & Recruiting \\
\hline JROSG10-1 & $\begin{array}{l}\text { Dose escalation study for centrally located stage I NSCLC (started from } \\
60 \mathrm{~Gy} / 8 \mathrm{fx} \text { ) }\end{array}$ & Recruiting \\
\hline RTOG0915 & $\begin{array}{l}\text { Randomized study for medically inoperable stage I NSCLC ( } 34 \mathrm{~Gy} / 1 \mathrm{fx} \text { ver- } \\
\text { sus } 48 \mathrm{~Gy} / 4 \mathrm{fx} \text { ) }\end{array}$ & Recruiting \\
\hline ACOSOG Z4099/RTOG1021 & $\begin{array}{l}\text { Randomized study for high risk patients with stage I NSCLC (SBRT versus } \\
\text { surgery }+/- \text { brachytherapy) }\end{array}$ & Recruiting \\
\hline
\end{tabular}

腺癌 40 , 扁平上皮癌 21 , その他 4 であり, performance status (PS) は 0/1/2=43/20/2 であった。 中間観察期間 45 ヶ月で, 3 年生存割合 $76 \%, 3$ 年局所無増悪生存割合 $69 \%$ であった. grade 3 以上の有害事象として胸痛 1 , 呼 吸困難 2 , 低酸素血症 1 , 放射線肺臓炎 2 を認めたが, grade 4 以上の有害事象は認めなかった.

\section{8. 手術可能患者に対する手術との第 III 相試験（無 作為比較試験)}

前述のように, JCOG0403 の報告が手術可能症例に対 する世界初の第 II 相試験結果であったが, それに先駆け て2つの手術との無作為比較試験が開始されている.

MD Anderson Cancer Center を代表とするサイバーナ イフを用いた国際多施設試験 (STARS) 21 と, オランダ の VU University Medical Centerを代表とした ROSEL 22 である.

これらの試験は, 前述の手術可能症例に対する世界初 の第 II 相試験結果が出る以前に開始されたもので, rationale が十分でない上に, 手術との比較試験ということ で患者集積が困難を極め，前者は患者の選択を許容する こととなり，後者は試験中止に追い込まれたとのことで ある。

\section{9. その他現在進行中の臨床試験}

調べられる限りで現在世界で肺癌に対して 50 件以上 のさまざまな定位放射線治療に関する臨床試験が施行さ れている. その中で注目されているものを Table 3 にま とめる. 前述の試験の他, RTOG0618 は手術可能な T1 3N0M0 非小細胞肺癌に対する第 II 相試験, RTOG0813 と JROSG10-1 は気管や葉気管支近傍の中心型肺癌に対 する投与線量についての線量増加試験, RTOG0915 は I 期非小細胞肺癌に対する 1 回照射法と 4 回照射法の安全 性と有効性に関する試験, ACOSOG Z4099/RTOG1021 は I 期非小細胞肺癌で肺葉切除困難症例に対する定位放 射線治療と部分切除 $+/$ - 小線源治療の無作為比較試験
である．またこの他，白土らによって組織未確定小型肺 癌への定位放射線治療の有効性と安全性についての前向 き試験が施行されており，現在症例蓄積中である.

\section{0. 未解決な今後の課題}

これまで多くの臨床試験が行われてきたが, 以下のよ うな未解決な課題が数多く残されており, これまでの臨 床試験の長期経過観察と今後の新たな臨床試験構築に よって解決されていくべきであると考える.

(1)より明確な適応と安全性

(2)最適な線量と分割方法

(3)異なる線量分割の照射法による生物学的効果の比較 方法

(4)補助療法・再発後の治療

(5)長期予後（10 年以上）

\section{1. 考察}

体幹部腫瘍に対する定位放射線治療は未だ歴史が浅く 症例数も十分でないため, 治療成績の正当な評価には今 後も症例蓄積と十分な経過観察が必要である。また, 腫 瘍の部位や肺基礎疾患など，適応の選択にも注意が必要 である．肺癌に対する定位放射線治療の有効性のエビデ ンスは十分ではないが, 適切な対象を選べば患者にとっ て有意義な治療法の選択肢となりうる可能性がある。今 後その位置づけをさらに明らかにするために, 現在行わ れている臨床試験の進渉を待つとともに, 新たな臨床試 験を構築していく必要がある. 外科的手法との比較では, 今後 JCOG0403 の長期成績が安定したものであれば，低 肺機能や全身状態により標準手術が困難な（縮小手術が 検討されるような)いわゆる high risk または marginally operable と言われている症例群を対象にして, 縮小手術 と定位放射線治療の比較試験が日本でも検討されても良 いかもしれない，また，定位放射線治療はリンパ節転移 についての診断を欠くため, 現在肺癌外科グループで遂 行されている JCOG0804/WJOG4507L の結果で, 小型で 
ground glass opacity（GGO）成分を含むような腫瘍にお いてリンパ節転移の可能性の低い対象を特定できるよう になれば，そのような症例群に対する定位照射の有用性 を明らかにする臨床試験の意義があるだろう.

\section{2. おわりに}

体幹部定位放射線治療は開始から 15 年を経て, 今なお 以下のような技術的進歩を重ねている. (1)治療計画時の 計算アルゴリズムの高精度化と高速化，(2)照射装置の小 型化と高線量率化, (3)呼吸性移動対策の高精度化などで ある.これらの先端技術が治療効果に結びつくかどうか は今後の検証が必要であるが, 今後も「より正確により 集中的に」照射する技術進歩が期待される。このような 今後も変化が予測される定位放射線治療が適切に臨床応 用されるために，不明なクリニカルクエスチョンに答え るための新たな臨床試験の実施とともに，既に得られた 臨床試験結果について，それぞれの時代における照射技 術によって検証と見直しが必要であると考える.

本論文内容に関連する著者の利益相反：なし

\section{REFERENCES}

1. Uematsu M, Fukui T, Shioda A, Tokumitsu H, Takai K, Kojima T, et al. A dual computed tomography linear accelerator unit for stereotactic radiation therapy: a new approach without cranially fixated stereotactic frames. Int J Radiat Oncol Biol Phys. 1996;35:587-592.

2. Shirato H, Shimizu S, Shimizu T, Nishioka T, Miyasaka K. Real-time tumour-tracking radiotherapy. Lancet. 1999; 353:1331-1332.

3. 大西 洋, 平岡真寛. 詳説 - 体幹部定位放射線治療 ガイ ドラインの詳細と照射マニュアル. 東京：中外医学社； 2006.

4. Nagata Y, Hiraoka M, Mizowaki T, Narita Y, Matsuo Y, Norihisa Y, et al. Survey of stereotactic body radiation therapy in Japan by the Japan 3-D Conformal External Beam Radiotherapy Group. Int J Radiat Oncol Biol Phys. 2009;75:343-347.

5. Onishi H, Kuriyama K, Komiyama T, Tanaka S, Sano N, Marino K, et al. Clinical outcomes of stereotactic radiotherapy for stage I non-small cell lung cancer using a novel irradiation technique: patient self-controlled breath-hold and beam switching using a combination of linear accelerator and CT scanner. Lung Cancer. 2004;45: 45-55.

6. Timmerman R, Papiez L, McGarry R, Likes L, DesRosiers C, Frost S, et al. Extracranial stereotactic radioablation: results of a phase I study in medically inoperable stage I non-small cell lung cancer. Chest. 2003;124: 1946-1955.

7. McGarry RC, Papiez L, Williams M, Whitford T, Timmerman RD. Stereotactic body radiation therapy of early-stage non-small-cell lung carcinoma: phase I study.
Int J Radiat Oncol Biol Phys. 2005;63:1010-1015.

8. Onimaru R, Fujino M, Yamazaki K, Onodera Y, Taguchi $\mathrm{H}$, Katoh N, et al. Steep dose-response relationship for stage I non-small-cell lung cancer using hypofractionated high-dose irradiation by real-time tumor-tracking radiotherapy. Int J Radiat Oncol Biol Phys. 2008;70:374-381.

9. Onishi H, Shirato H, Nagata Y, Hiraoka M, Fujino M, Gomi K, et al. Hypofractionated stereotactic radiotherapy (HypoFXSRT) for stage I non-small cell lung cancer: updated results of 257 patients in a Japanese multiinstitutional study. J Thorac Oncol. 2007;2(Suppl 3):S94S100.

10. Uematsu M, Shioda A, Suda A, Fukui T, Ozeki Y, Hama $\mathrm{Y}$, et al. Computed tomography-guided frameless stereotactic radiotherapy for stage I non-small cell lung cancer: a 5-year experience. Int J Radiat Oncol Biol Phys. 2001;51: 666-670.

11. Hof H, Herfarth KK, Münter M, Hoess A, Motsch J, Wannenmacher M, et al. Stereotactic single-dose radiotherapy of stage I non-small-cell lung cancer (NSCLC). Int J Radiat Oncol Biol Phys. 2003;56:335-341.

12. Takeda A, Sanuki N, Kunieda E, Ohashi T, Oku Y, Takeda $\mathrm{T}$, et al. Stereotactic body radiotherapy for primary lung cancer at a dose of $50 \mathrm{~Gy}$ total in five fractions to the periphery of the planning target volume calculated using a superposition algorithm. Int J Radiat Oncol Biol Phys. 2009;73:442-448.

13. Onishi H, Shirato H, Nagata Y, Hiraoka M, Fujino M, Gomi K, et al. Stereotactic body radiotherapy (SBRT) for operable stage I non-small-cell lung cancer: can SBRT be comparable to surgery? Int J Radiat Oncol Biol Phys. 2011; 81:1352-1358.

14. Nagata Y, Takayama K, Matsuo Y, Norihisa Y, Mizowaki $\mathrm{T}$, Sakamoto T, et al. Clinical outcomes of a phase I/II study of 48 Gy of stereotactic body radiotherapy in 4 fractions for primary lung cancer using a stereotactic body frame. Int J Radiat Oncol Biol Phys. 2005;63:1427-1431.

15. Zimmermann FB, Geinitz H, Schill S, Thamm R, Nieder C, Schratzenstaller U, et al. Stereotactic hypofractionated radiotherapy in stage I (T1-2 N0 M0) non-small-cell lung cancer (NSCLC). Acta Oncol. 2006;45:796-801.

16. Timmerman R, McGarry R, Yiannoutsos C, Papiez L, Tudor K, DeLuca J, et al. Excessive toxicity when treating central tumors in a phase II study of stereotactic body radiation therapy for medically inoperable earlystage lung cancer. J Clin Oncol. 2006;24:4833-4839.

17. Fakiris AJ, McGarry RC, Yiannoutsos CT, Papiez L, Williams M, Henderson MA, et al. Stereotactic body radiation therapy for early-stage non-small-cell lung carcinoma: four-year results of a prospective phase II study. Int J Radiat Oncol Biol Phys. 2009;75:677-682.

18. Baumann P, Nyman J, Lax I, Friesland S, Hoyer M, Rehn Ericsson S, et al. Factors important for efficacy of stereotactic body radiotherapy of medically inoperable stage I lung cancer. A retrospective analysis of patients treated in the Nordic countries. Acta Oncol. 2006;45:787795.

19. Ricardi U, Filippi AR, Guarneri A, Giglioli FR, Ciammella P, Franco P, et al. Stereotactic body radiation therapy 
for early stage non-small cell lung cancer: results of a prospective trial. Lung Cancer. 2010;68:72-77.

20. Timmerman R, Paulus R, Galvin J, Michalski J, Straube $\mathrm{W}$, Bradley J, et al. Stereotactic body radiation therapy for inoperable early stage lung cancer. JAMA. 2010;303: 1070-1076.

21. http://clinicaltrials.gov/ct2/show/NCT00840749

22. http://clinicaltrials.gov/ct2/show/NCT00687986 